\title{
THE POLISH-UKRAINIAN BORDER AS A METHODOLOGICAL, COGNITIVE AND APPLICATIONAL CHALLENGE
}

\author{
ANDRZEJ MISZCZUK \\ Centre for European Regional and Local Studies EUROREG \\ University of Warsaw \\ Krakowskie Przedmieście 30, 00-927 Warszawa, Poland \\ e-mail: a.miszczuk@uw.edu.pl
}

\begin{abstract}
The national border between Poland and Ukraine is a typical subsequent boundary, delimited after World War II as the then border between Poland and the Soviet Union. Since May 1st 2004, it has been the external European Union border, and since December 21st 2007—of the Schengen Area. It constitutes an interesting research object in terms of its methodological, cognitive and applicational characteristics. This paper comprises deliberations pertaining to the three aspects mentioned above.
\end{abstract}

Key words: Polish-Ukrainian border, Polish-Ukrainian borderland, cross-border cooperation, Poland, Ukraine

\section{INTRODUCTION}

Since the turn of the 1980s and 90s, Europe has seen the emergence of a number of new states, and consequently the establishment of a number of new national borders. Central and Eastern Europe has been particularly dynamic in this respect. As rightfully observed by M. Leibenath (2008), of the 10 new Member States that joined the European Union in 2004, 6 (the Czech Republic, Estonia, Lithuania, Latvia, Slovakia, and Slovenia) had not existed 20 years earlier. The process was also of significant consequence to Poland. Whereas at the end of the 1980s, Poland bordered with only three countries (the GDR, Czechoslovakia, and the USSR), in the mid 1990s, the number reached seven (Germany, the Czech Republic, Slovakia, Ukraine, Belarus, Lithuania, and Russia). Ukraine is one of the new states established in the early 1990s. The national border between Poland and Ukraine is a typical subsequent boundary, delimited after World War II as the then border between Poland and the Soviet Union. Since May 1st 2004, it has been the external European 
Union border, and since December 21st 2007—of the Schengen Area. It constitutes an interesting research object in terms of its methodological, cognitive and applicational characteristics. This paper comprises deliberations pertaining to these three aspects of research.

\section{POLISH-UKRAINIAN BORDER-THE METHODOLOGICAL ASPECT}

National boundaries constitute one of the main research fields in geography, particularly political geography. The traditional understanding of boundaries, dating back to the works of F. Ratzel, defined them as demarcation lines delimiting the spatial dimensions of a given state/nation. The focus of this approach-referred to as boundary studies, which dominated the discipline until the 1960s, was the analysis of various factors determining the layout, evolution and changes of national lines. In contrast, modern border studies adopt a more multidimensional approach, treating a border as a socio-spatial construct through which existing diversities can be communicated (H.van Houtum 2005). The scope of interest of border studies covers (Newman and Passi 2001), among other elements:

- the phenomena of disappearing national borders,

- building socio-spatial identities,

- boundaries of admission and exclusion,

- borders viewed in various spatial scales.

Modern deliberations pertaining to national borders are dominated by the postmodernist approach, as clearly visible in the optimistic attitude to the disappearance of state lines as spatial barriers. It is largely due to the impact of globalisation and the related freedom of information flow that led to the substitution of the space of places with the space of flows, which in turn means that the national state no longer constitutes a singular entity in international economic relations of the "borderless world" and open markets free of commercial barriers. It turns out, however, that such phenomena are mainly the experience of Western European countries, the USA or Canada, while in the post-Soviet states of the early 1990s, one could observe a revival of nationalistic states and the delimitation of their borders as spatial barriers. Furthermore, it is noteworthy that the disappearance of borders in the economic sense is not synonymous with their disappearance in other areas of human activity (Newman and Passi 2001).

A fairly popular instrument utilised in the analysis of the evolving character of borders is provided by the Martinez model (1994), which comprises a sequence of four stages, i.e.:

- the stage of hostility,

- the stage of coexistence,

- the stage of cooperation,

- the stage of interdependence. 
The stage of hostility is typically the consequence of violent political events that threaten the existence of a state, the integrity of its territory and borders. In such circumstances state borders serve a dividing or disintegrative function, consequently severing any international, i.e. also cross-border, relations. The same may also result from international sanctions being taken against a given country (Moraczewska 2008).

The transition from the stage of hostility to the stage of coexistence requires time. As noted by R.J. Bennet (1997), the process is easier when the commencement of cooperation between administrative entities and border regions is stimulated, among other factors, by elements of the functional space (economic, socio-cultural, etc.) exceeding administrative or state boundaries.

The shift from the border of hostility to the border of coexistence is also relatively easier when the regions on both sides of the border are autonomous or self-governing. It is significantly more difficult to initiate interregional cooperation when even one of the countries involved is highly centralised, as a far greater involvement of the central government is then required.

Institutional incompatibilities, manifested in the varied competence of local and regional authorities on either side of the national border, also known as the institutional-organisational distance between regions (Gorzelak 2002), are-alongside the cultural and language distance-among the most commonly quoted barriers to cross-border cooperation (Ciok 1998).

The phase of the border of coexistence may also be defined as the phase of information exchange (Ricq 1995). The process takes place on various levels and between various entities. It facilitates becoming acquainted with the partners on the other side of the border, the organisation of public administration, laws and regulations in terms of customs, taxation and other business related areas, scenic and tourist attractions, elements of material and non-material culture.

With the transition to the stage of cooperation, the cross-border contacts become further intensified. The process takes place mainly on the levels of: public safety, particularly in terms of natural disasters and crime, education, scientific research, culture and sports. The stage also sees further development of commerce, including its spontaneous, non-evidenced instances, stimulated by price variations on either side of the border.

The function of a border in both the coexistence and cooperation stages can be described, after J. Rosenau, as fragmengrative, which means being open to only certain factors or varying the level of openness towards particular states (Moraczewska 2008).

The stage of interdependence involves further tightening of the cross-border regional bonds, through technological and capital connections, workforce flows, and common ventures undertaken on a partnership basis. Serving an integrative function, the border becomes practically imperceptible, which can be seen as the desirable target state of affairs in this respect. The stage can only be reached in conditions of far- 
reaching economic integration between states in the form of an economic or customs unions and common market provisions.

The process of transition from a dividing (closed) border, through a filtering one, and eventually to the stage of an integrative (open) border is a lengthy and often not unidirectional process. Turnabouts towards any of the earlier stages are a possibility, and can often take violent, even dramatic forms.

The current Polish-Ukrainian border is $535 \mathrm{~km}$ long, which constitutes $15.4 \%$ of the total span of the Polish state lines and $6.9 \%$ of all Ukrainian borders (Figure 1). It stretches from the area around Włodawa in the north to the line of the Carpathians in the south. It cuts across latitudinal transborder physiographic units: Polesie, the Lublin-Lviv Upland, the Volhyn Upland, Roztocze, and the Eastern Beskids (Bieszczady) (Figure 2).

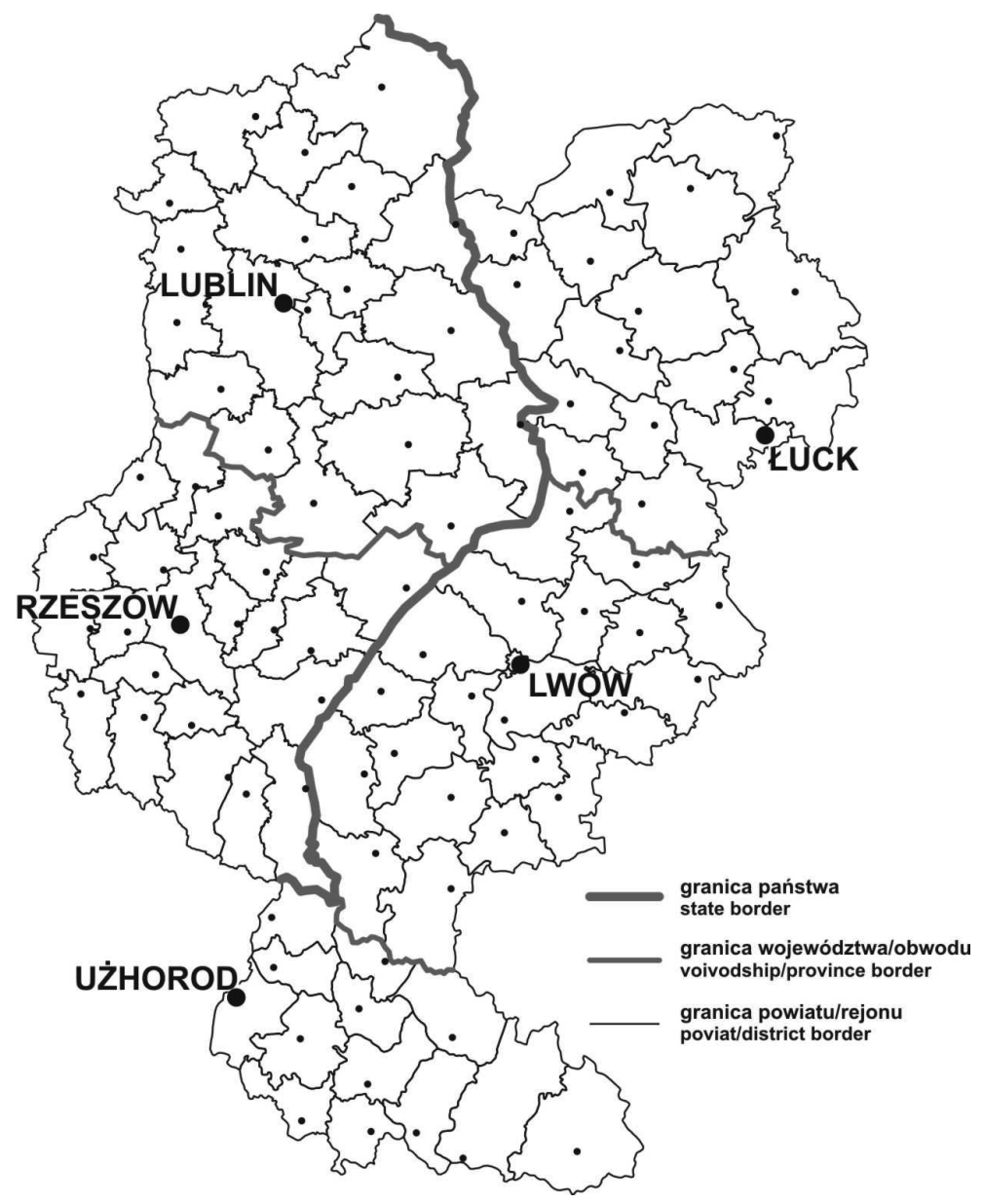

Figure 1. The Polish-Ukrainian border and the surrounding borderlands Source: author's own research. 
On the one hand, the border can be, at least to some extent, considered a natural border-201 km of its total span is delimited by the river Bug, on the other however, from the historical perspective, the Bug had rarely been a border river as it would typically flow through the territory of one state-the Kingdom of Galicia-Volhynia, Poland, Russia (from 1815 to 1918) and again Poland. A similar situation can be observed in the case of Zakarpattia, which belonged, in succession to: Hungary, Austria, Austria-Hungary, and Czechoslovakia. Therefore it seems justified to observe that the Polish-Ukrainian border, as delimited in 1945, was a new phenomenon (Bałtowski, Miszczuk 1999).

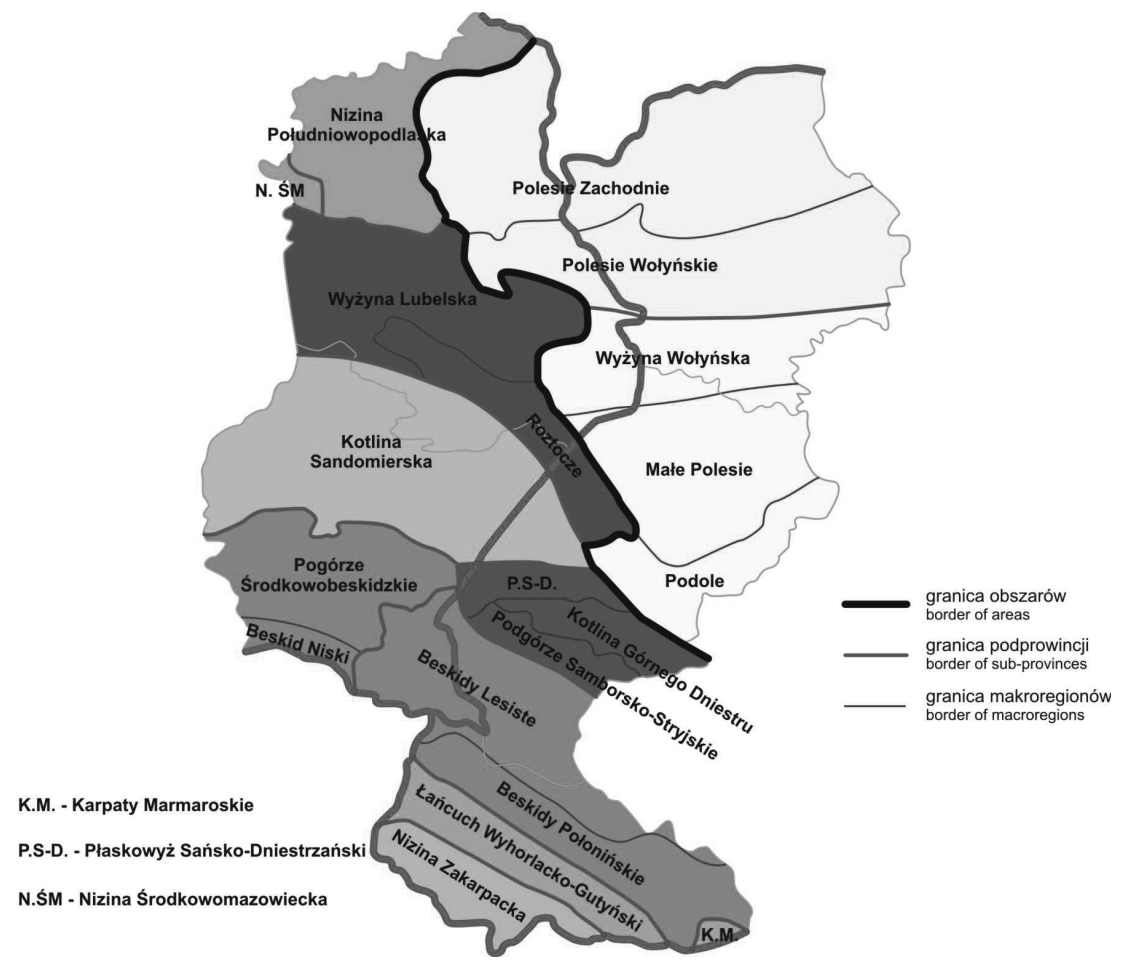

Figure 2. The Polish-Ukrainian border and the adjacent physiographic units Source: W. Żuchowski (2005).

Once conclusively established in 1951, a process that involved a territorial and populational exchange between Poland and the USSR, the border entered the stage of hostility (closed border), which continued until 1991, i.e. the year of Ukraine's independence. The period was characterised by very low permeability of the border, both in physical and technical terms ${ }^{1}$ as well as politically and legally, which resulted in severing numerous functional and spatial bonds that used to exist between the Lublin Region, the Carpathian, Volhynia, Lviv Voivodship, and Zakarpattia.

\footnotetext{
${ }^{1}$ Until 1990, only three crossings existed on the Polish-Ukrainian border, i.e. the railway crossing for passenger and freight traffic in Przemyśl, passenger and freight road crossing in Medyka, and freight railway crossing in Hrubieszów.
} 
It also diminished the status of a number of cities, particularly smaller ones, and led to the borderland regions' reduction to a peripheral area, in geographic, but most importantly economic terms. Since the early 1990 s, the Polish-Ukrainian border has entered a transitory phase-among other factors due to the opening of new border crossings and the introduction of visa-free traffic - which may be defined as a border of coexistence verging, at least in some aspects, on cooperation (Table 1), while maintaining its fragmengrative character, as conditioned by geopolitical circumstances.

Table 1. Evolution of the phases and functions of the Polish-Ukrainian border

\begin{tabular}{|l|c|c|}
\hline \multicolumn{3}{|c|}{ Polish-Soviet Border } \\
\hline \multicolumn{1}{|c|}{ period } & phase & function \\
\hline $1945-1951$ & coexistence & fragmengrative \\
\hline $1951-1991$ & hostility & disintegrative \\
\hline \multicolumn{2}{|c|}{ Polish-Ukrainian Border } \\
\hline \multicolumn{2}{|c|}{ phase } & function \\
\hline $1991-2004$ & coexistence with elements of cooperation & fragmengrative \\
\hline $2004-2007$ & coexistence with elements of cooperation & fragmengrative \\
\hline $2007-$ & coexistence with elements of cooperation? & fragmengrative? \\
\hline
\end{tabular}

Source: author's own research.

Further evolution in terms of functions and phases, following the Martinez model, seems rather unlikely in the perspective of the next two decades, particularly since Ukraine has taken no active steps towards obtaining even the status of an EU Associated State. With Poland's progressing integration with the EU, the spatial barrier of the Polish-Ukrainian border is being continually strengthened. In 2003, visas were introduced for Ukrainian citizens, and as Poland joined the Schengen area, the visa requirements had to be further tightened. As a result, the crossborder traffic of Ukrainian citizens significantly decreased. In its current function, the Polish-Ukrainian border is conductive to deepening the already apparent economic disproportions, clearly visible in the development level of the Polish section of the borderlands (Lubelskie and Podkarpackie [subcarpatian] voivodships) measured by the per capita added value. Should we compare the value to that of the Ukrainian counterparts (Lviv, Volhyn and Zakarpattia Oblasts), the ratio for 2005 was 3.9:1; while a juxtaposition of said values for the Podkarpackie Voivodship and Zakarpattia alone was 4.5:1.

One of the main impediments to Polish-Ukrainian cross-border cooperation is the persistent distance observed on the institutional and organisational level, as Ukraine does not have self-governmental structures consistent with the standards of the European Charter of Local Self-Government. It is therefore apparent that the West European experience of border evolution cannot be directly applied to 
the group of post-Soviet states such as Ukraine. Consequently, it is necessary to develop a new theoretical model to reflect the specifics of the EU's outer border with states that were formerly part of the USSR, characterised by a significant institutional and organisational dissonance, as well as notably slower rates of social and economic development when compared to those observed in EU Member States. Additionally, the level of mistrust towards the process of European integration is relatively high in those countries, despite the fact that the border is indeed a subsequent one as it cuts across formerly existing common functional spaces.

\section{POLISH-UKRAINIAN BORDER-THE COGNITIVE ASPECT}

One of the most important activities that facilitate the transition from dividing, through filtrating and towards an open border, is the provision of reliable information on the neighbouring states. In the case of the Polish-Ukrainian border, with the establishment of the Carpathian Euroregion (1993) and Bug Euroregion (1995), the task fell to the Statistical Offices in Rzeszów (Krosno) and Lublin. Table 2 presents a list of the two institutions' publications between 1995 and 2009.

Table 1. Evolution of the phases and functions of the Polish-Ukrainian border

\begin{tabular}{|c|c|c|c|c|c|}
\hline Title & Subject & $\begin{array}{c}\text { Spatial } \\
\text { cross-section }\end{array}$ & $\begin{array}{l}\text { Language } \\
\text { versions }\end{array}$ & Publisher & Year \\
\hline $\begin{array}{l}\text { The Bug Euroregion in } \\
\text { figures }\end{array}$ & $\begin{array}{l}\text { socio-economic } \\
\text { characteristics }\end{array}$ & $\begin{array}{l}\text { voivodships, } \\
\text { oblasts, cities }\end{array}$ & $\begin{array}{l}\text { Polish and } \\
\text { English }\end{array}$ & $\begin{array}{c}\text { SO } \\
\text { Lublin }\end{array}$ & 1995 \\
\hline $\begin{array}{l}\text { The Bug Euroregion- } \\
\text { facts and figures }\end{array}$ & $\begin{array}{l}\text { socio-economic } \\
\text { characteristics }\end{array}$ & $\begin{array}{l}\text { voivodships, } \\
\text { oblasts, cities, } \\
\text { gminas }\end{array}$ & $\begin{array}{l}\text { Polish and } \\
\text { Ukrainian }\end{array}$ & $\begin{array}{l}\mathrm{SO} \\
\text { Lublin }\end{array}$ & 1996 \\
\hline $\begin{array}{l}\text { City network in the } \\
\text { Carpathian Euroregion. } \\
\text { Basic statistical data. }\end{array}$ & $\begin{array}{l}\text { socio-demographic } \\
\text { structures and } \\
\text { changes }\end{array}$ & cities & Polish-English & $\begin{array}{c}\text { SO } \\
\text { Krosno }\end{array}$ & 1997 \\
\hline $\begin{array}{l}\text { Cities in the Bug } \\
\text { Euroregion }\end{array}$ & $\begin{array}{l}\text { socio-economic cha- } \\
\text { racteristics of cities }\end{array}$ & cities & Polish & $\begin{array}{c}\mathrm{SO} \\
\text { Lublin }\end{array}$ & 1997 \\
\hline $\begin{array}{l}\text { Population in the } \\
\text { Carpathian Euroregion }\end{array}$ & $\begin{array}{l}\text { socio-demographic } \\
\text { structures and } \\
\text { changes }\end{array}$ & $\begin{array}{l}\text { voivodships, } \\
\text { oblasts, poviats, } \\
\text { districts }\end{array}$ & Polish-English & $\begin{array}{c}\mathrm{SO} \\
\text { Rzeszów }\end{array}$ & 1999 \\
\hline $\begin{array}{l}\text { Polish-Ukrainian } \\
\text { Borderland in figures }\end{array}$ & $\begin{array}{l}\text { socio-economic } \\
\text { characteristics }\end{array}$ & $\begin{array}{l}\text { voivodships, } \\
\text { oblasts, poviats, } \\
\text { regions }\end{array}$ & $\begin{array}{c}\text { Polish- } \\
\text { Ukrainian, } \\
\text { Polish-English }\end{array}$ & $\begin{array}{c}\mathrm{SO} \\
\text { Lublin }\end{array}$ & 1999 \\
\hline $\begin{array}{l}\text { The Bug Euroregion in } \\
\text { figures }\end{array}$ & $\begin{array}{l}\text { socio-economic } \\
\text { characteristics }\end{array}$ & $\begin{array}{l}\text { voivodships, } \\
\text { oblasts, poviats, } \\
\text { districts }\end{array}$ & $\begin{array}{l}\text { Polish- } \\
\text { Ukrainian, } \\
\text { Polish-English }\end{array}$ & $\begin{array}{c}\mathrm{SO} \\
\text { Lublin }\end{array}$ & 2000 \\
\hline $\begin{array}{l}\text { Infrastructure in the } \\
\text { Carpathian Euroregion }\end{array}$ & $\begin{array}{l}\text { technical and social } \\
\text { infrastructure }\end{array}$ & $\begin{array}{l}\text { voivodships, } \\
\text { oblasts }\end{array}$ & $\begin{array}{l}\text { Hungarian- } \\
\text { English }\end{array}$ & $\begin{array}{c}\text { SO } \\
\text { Debrecen }\end{array}$ & 2000 \\
\hline $\begin{array}{l}\text { Population in the } \\
\text { Carpathian Euroregion }\end{array}$ & $\begin{array}{l}\text { socio-demographic } \\
\text { structures and } \\
\text { changes }\end{array}$ & $\begin{array}{l}\text { voivodships, } \\
\text { oblasts, poviats, } \\
\text { districts }\end{array}$ & Polish-English & $\begin{array}{c}\mathrm{SO} \\
\text { Rzeszów }\end{array}$ & 2002 \\
\hline
\end{tabular}




\begin{tabular}{|c|c|c|c|c|c|}
\hline $\begin{array}{l}\text { Cities in the Carpathian } \\
\text { Euroregion in } \\
\text { 1998-2000 }\end{array}$ & $\begin{array}{c}\text { social infrastructure } \\
\text { of cities }\end{array}$ & cities & Slovak-English & $\begin{array}{c}\text { SO } \\
\text { Kosice }\end{array}$ & 2002 \\
\hline $\begin{array}{l}\text { Lviv Oblast and } \\
\text { Lubelskie Voivodship in } \\
\text { figures }\end{array}$ & $\begin{array}{l}\text { economic potential } \\
\text { analysis }\end{array}$ & $\begin{array}{l}\text { voivodships, } \\
\text { oblasts }\end{array}$ & $\begin{array}{l}\text { Ukrainian- } \\
\text { Polish }\end{array}$ & $\begin{array}{l}\text { SO } \\
\text { Lviv }\end{array}$ & 2003 \\
\hline $\begin{array}{l}\text { Population and housing } \\
\text { conditions in the Bug } \\
\text { Euroregion }\end{array}$ & $\begin{array}{l}\text { population and living } \\
\text { conditions characte- } \\
\text { ristics based on cen- } \\
\text { suses (Belarus-1999, } \\
\text { Ukraine-2001, } \\
\text { Poland-2002). }\end{array}$ & $\begin{array}{l}\text { voivodships, } \\
\text { oblasts, poviats, } \\
\text { district }\end{array}$ & Polish-English & $\begin{array}{c}\text { SO } \\
\text { Lublin }\end{array}$ & 2004 \\
\hline $\begin{array}{l}\text { Cities_regional capitals } \\
\text { of the Bug Euroregion } \\
\text { in } 2005\end{array}$ & $\begin{array}{l}\text { socio-economic } \\
\text { characteristics of } \\
\text { Brześć, Lublin, Lviv } \\
\text { and Łuck }\end{array}$ & $\begin{array}{l}\text { voivodships, } \\
\text { oblasts, cities on } \\
\text { poviat/district } \\
\text { rights }\end{array}$ & Polish-English & $\begin{array}{c}\text { SO } \\
\text { Lublin }\end{array}$ & 2007 \\
\hline $\begin{array}{l}\text { Lviv Oblast and Lubel- } \\
\text { skie Voivodship in } \\
\text { figures }\end{array}$ & $\begin{array}{l}\text { economic potential } \\
\text { analysis }\end{array}$ & $\begin{array}{l}\text { voivodships } \\
\text { oblasts }\end{array}$ & $\begin{array}{l}\text { Ukrainian- } \\
\text { Polish }\end{array}$ & $\begin{array}{l}\text { SO } \\
\text { Lviv }\end{array}$ & $\begin{array}{l}2006- \\
-2009\end{array}$ \\
\hline $\begin{array}{l}\text { Polish-Ukrainian } \\
\text { Borderland in figures } \\
\text { in } 2006\end{array}$ & $\begin{array}{l}\text { socio-economic } \\
\text { characteristics }\end{array}$ & $\begin{array}{l}\text { voivodships, } \\
\text { oblasts, poviats, } \\
\text { districts }\end{array}$ & $\begin{array}{l}\text { Polish, } \\
\text { English, } \\
\text { Ukrainian }\end{array}$ & $\begin{array}{l}\text { SO } \\
\text { Lublin }\end{array}$ & 2007 \\
\hline $\begin{array}{l}\text { Polish-Slovak-Ukrainian } \\
\text { Borderland }\end{array}$ & $\begin{array}{l}\text { environmental pro- } \\
\text { tection, demographic } \\
\text { conditions, labour } \\
\text { market, businesses, } \\
\text { GDP, agriculture, } \\
\text { tourism }\end{array}$ & $\begin{array}{l}\text { voivodships, } \\
\text { regions, oblasts }\end{array}$ & Polish-English & $\begin{array}{c}\text { SO } \\
\text { Rzeszów }\end{array}$ & 2009 \\
\hline
\end{tabular}

Source: author's own research.

The above outline of the publishing activity of statistical offices offers several insights. Firstly, while the initial initiatives originated mostly from Polish statistical offices, in recent years the activity of their Ukrainian counterparts has significantly improved.

Secondly, the publications most commonly pertain to demographic problems, while the most sought-after economic analyses are still the most problematic, despite the introduction of European classifications and nomenclature into Ukrainian statistics, which greatly improves data comparability.

Thirdly, the smallest spatial unit allowing presentation of statistical information on Ukraine is a district and a city on oblast (voivodship) level, which corresponds to Polish poviats and cities on poviat rights.

Fourthly, it would be advisable to replace the seeming spontaneity in terms of said publishing activity with a more systematic approach, particularly through regular publication of statistical yearbooks pertaining to the Polish-Ukrainian borderland, and maintaining selected thematic series.

The already existing cross-border exchange of statistical information between Poland and Ukraine would seem to validate the qualitatively new initiative in this area, namely the establishment of a transborder databank utilising the GIS technology. 
Its goals could include (Miszczuk 2005):

- creating an international, freely accessible (via the internet) data pool,

- eliminating the language barrier in the utilisation of international statistical data by consistently adhering to the rule of multilingualism,

- harmonizing statistical date.

The databank could comprise information pertaining to, among other things: regional, local and administrative divisions, natural environment-its exploitation and protection, demographic processes and structures, national accounts in regional and subregional depiction, social infrastructure (education, healthcare, culture, and tourism), local and regional finance. The data should be available in NUTS-1, 2 and 3 subdivisions. Such Polish-Ukrainian cross-border databank could be financed under the Cross-Border Cooperation Programme Poland-Ukraine-Belarus 2007-2013.

It is notable that Polish statistical authorities, apart publications on areas located on both sides of the Polish-Ukrainian border, also conduct surveys pertaining to various cross-border traffic and flows. The driving force behind border traffic used to be, and to a large extent still is, cross-border commerce (bazaar trade), which constituted the main source of income for numerous small businesses and natural persons. Its earliest stage (1990-1993) was basically a deluge of cheap, often poorquality products brought from Ukraine to Poland. Once they were sold, the entrepreneurs exchanged the earnings into dollars and carried them back to Ukraine. The subsequent stage (1994-1998) saw a reversal of the merchandise and money flows. Severe product shortages on the Ukrainian market encouraged Ukrainian citizens to come to Poland to shop for specific goods (particularly groceries-fruit, vegetables and fish, and such products as clothes, furniture or building materials). Cross-border commerce boomed in gminas that had their own border crossings and in cities located within $100 \mathrm{~km}$ from the border. Since 1999, cross-border commerce has followed a pattern of what could be described as the third stage of its development. The importance of the trade has gradually declined, undoubtedly due to the growing economic activity on the Ukrainian side. Much of the demand for services and products is now being satisfied by local producers and international businesses that entered the Ukrainian market. Not without consequence is also the limit introduced by the Ukrainian government on the amount of goods that can be carried into the country.

The analysis of border traffic, with its reasons and economic consequences, was made possible by the extensive research conducted in 1994-2002 by the Central Statistical Office on all border crossings in Poland, including those between Poland and Ukraine, whose results were published annually in a yearbook entitled: Border traffic and the spending of foreign visitors to Poland and Polish citizens abroad. Since the 3rd quarter of 2008 the research has been reinstated and carried out by the Statistical Office in Rzeszów aided by the Statistical Office in Lublin, in cooperation with the Border Guard and the Customs Service, with the aim of analysing the sales of goods and services in the border traffic on the Polish-Ukrainian border. The study 
covered all road and railway crossings for passenger traffic. The results of the study indicate that ${ }^{2}$ :

- the estimated value of goods and services purchased in Poland by foreigners crossing the Polish-Ukrainian border between January and September of 2009 amounted to PLN 1,465.2 million, while the respective spending of Polish citizens abroad in the same period amounted to PLN 300.4 million,

- in the 3rd quarter of 2009, the spending of foreigners was PLN 596.1 million, and of Polish citizens PLN 117.1 million, which constituted an increase of respectively $19.3 \%$ and $16.4 \%$ when compared to the 2 nd quarter,

- the highest intensity of phenomena related to border traffic can be observed in the area of approximately $50 \mathrm{~km}$ from the border, as indicated e.g. by the percentage of people crossing the border who then spend money in this area (over $73 \%$ of foreigners and over $91 \%$ of Polish citizens), as well as the fact that residents of this area constituted the majority of the total number of persons crossing the border (over $56 \%$ of foreigners and over $66 \%$ of Polish citizens),

- the value of purchases made in Poland by foreigners declaring Ukraine as their country of residence constituted approximately $23 \%$ of the total export value from Poland to Ukraine estimated for the 3rd quarter of 2009.

- the value of purchases made abroad by Polish citizens declaring Ukraine as their travel destination constituted approximately $14.9 \%$ of the total import value from Ukraine to Poland estimated for the 3rd quarter of 2009,

- the value of total purchases made in Poland by foreigners declaring Ukraine as their country of residence and crossing the Polish-Ukrainian border in the Lubelskie Voivodship, constituted approximately $21.0 \%$ of the mean quarterly export from the Lubelskie Voivodship; the corresponding proportion for the Podkarpackie Voivodship was $11.1 \%$.

- the value of total purchases made abroad by Polish citizens declaring Ukraine as their travel destination, who crossed the Polish-Ukrainian border in the Lubelskie Voivodship, constituted approximately $6.7 \%$ of the mean quarterly import from the Lubelskie Voivodship; the corresponding proportion for the Podkarpackie Voivodship was $2.6 \%$.

\section{POLISH-UKRAINIAN BORDER-THE APPLICATIONAL ASPECT}

The quality of a border and the uniformity of a borderland are evidenced not only by the activity of its residents or businesses, but also of public authorities, particularly on the regional and local level. One of the most successful methods of overcoming border-related barriers is to prepare joint strategies for the development of the entire transborder region and naturally, their subsequent implementation.

\footnotetext{
2 http://www.stat.gov.pl/cps/rde/xbcr/rzesz/ASSETS_badanie__obrotow_IIIkw_2009.pdf
} 
On Polish initiative-in cooperation with Ukrainian representatives-as part of the Spatial and economic development project for the macro region of the Bialskopodlaskie, Chelmskie, Lubelskie and Tarnobrzeskie Voivodships (commissioned research project-PBZ-059-01), three studies were published pertaining to the above problem in the northern part of the Polish-Ukrainian borderland (as part of the Bug Euroregion), i.e.:

- Development strategy for the Bug Euroregion (Polski 1997),

- Study of spatial development directions for the Bug Euroregion (Dębski 1997),

- Environmental policy in the Bug Euroregion (Chmielewski 1997).

Furthermore, as part of the Neighbourhood Programme Poland-Ukraine-Belarus 2004-2006, works were initiated on the Common Polish-Ukrainian strategy for transboundary cooperation in 2005-2015 (2005), whose outline was completed in 2005 , while further works on the document continued in 2006. By way of endorsing the projects, a Letter of intent to devise a common transboundary strategy for cooperation between the Lubelskie and Podkarpackie Voivodships in Poland and the Lviv, Volhynia and Zakrpattia Oblasts in Ukraine was signed on October 6th 2005 in Lviv, by the marshals of Polish voivodships and the presidents of Ukrainian oblast authorities.

The main goal of the mentioned Strategy is to facilitate the development of the Polish-Ukrainian borderland by striving towards "excellent neighbourly relations, partnership and cooperation, balanced development, and better quality of life for residents", which is to be ensured by completing a number of priority tasks, sententiously specified as follows:

- cultural heritage (protection of the multicultural character, jointly shaping the image of the borderland),

- human resources (general quality improvement, tolerance, respect for distinctness),

- institutions and self-governance (development of the civic society, local self-governance, partnership and cooperation between self-governments),

- economy and entrepreneurship (tightening economic bonds, development of cooperation and institutional forms of facilitating business activity),

- space, natural resources and environmental protection (rational utilisation of space and natural resources, preservation and utilisation of natural assets to ensure balanced development),

- transport and communication (development of technological infrastructure, including compatible transport and communication networks).

Unfortunately any of the above stipulations has yet to be implemented. In fact, there is not even a common Polish-Ukrainian strategy in place concerning the development of border crossings and the related road infrastructure, a fact particularly inexplicable in the perspective of the upcoming European football championshipsEURO 2012 - which are to be jointly held by Poland and Ukraine. Should we treat the density of crossings on the Polish-German border in 2004 as appropriate for the EU's outer border, the Polish-Ukrainian border ought to expect 31 new cross- 
ings to open in the near future, while in fact currently only one is being built in Dołhobyczów-Uhrynów and one modernised in Dorohusk-Jagodzin. We can therefore conclude that for nearly 20 years, the Polish-Ukrainian border has not evolved past the stage of coexistence, which means that it still separates rather than unites the regions located on either side.

\section{CONCLUSION}

The Polish-Ukrainian border and the adjacent areas constitute an interesting object for research. It is subsequent in character, i.e. it separates areas which used to jointly comprise uniform functional spaces. The border's current character was greatly influenced by the period in history when Ukraine was part of the USSR and when, for nearly 40 years, the border was almost completely closed. Despite Ukraine's independence gained in 1991, the Polish-Ukrainian border still remains in the relatively early stage of development, described as the stage of coexistence. Any changes in this respect seem rather unlikely in the perspective of the nearest two decades considering, on the one hand, Poland's progressing integration with the EU, and on the other, Ukraine's policy of walking the fine line between pro-Russian and pro-European sentiments without decisively declaring for any of the two. Consequently, the disproportions between Polish and Ukrainian borderland regions become increasingly apparent, as is the respective institutional and organisational distance. Although fairly comprehensive statistical information is available on the Polish-Ukrainian borderland, no genuine attempts are being made to encourage common strategic initiatives in the area.

\section{REFERENCES}

Bałtowski, M. and Miszczuk, A. (1999), Granica polsko-ukraińska w perspektywie nowego europejskiego porządku geopolitycznego, Przeglad Zachodni, 3, 29-40.

Bennett, R. J. (1997), Administrative studies and economic space, Regional Studies, 31 (3), 323-336.

Chmielewski, T. J. (ed.), (1997), Skala przeksztatceń środowiska i polityka ekologiczna Euroregionu Bug, Euroregion Bug, 15, Norbertinum, Lublin.

Ciok, S. (1998), Bariery i ograniczenia wspólpracy transgranicznej (ze szczególnym uwzględnieniem granicy polsko-niemieckiej, in: Kitowski J. (ed.) Czynniki i bariery regionalnej wspótpracy transgranicznej-próba syntezy, UMCS-PTG, Rzeszów, 53-67.

Dębski, J. (1997), Studium kierunkowe zagospodarowania przestrzennego Euroregionu Bug, Euroregion Bug, 10, Norbertinum, Lublin. 
Gorzelak, G. (2002), Dynamika polskich regionów, in: Heffner K. (ed.) Uwarunkowania rozwoju regionalnego województwa opolskiego ze szczególnym uwzględnieniem migracji zagranicznych, Urząd Marszałkowski Województwa Opolskiego, Politechnika Opolska, Opole, 38-42.

van Houtum, H. (2005), The geopolitics of border and boundaries, Geopolitics, 10, $672-679$.

Leibenath, M. (2008), Exploring the gaps. Sustainability as a challenge for cross-border governance in Central Europe, in: Leibenath M., Korcelli-Olejniczak E., Knippschild R. (eds), Cross-border governance and sustainable spatial development, Springer Verlag, Berlin-Heidelberg, 1-11.

Martinez, O. (1994), The dynamics of border interaction: new approaches to border analysis, in: Schofield C. H. (ed.), Global Boundaries, World Boundaries, 1, Routledge, London, 1-15.

Miszczuk, A. (2005), Pogranicze polsko-ukraińskie jako przedmiot zainteresowania statystyki regionalnej, Wiadomości Statystyczne, 6, 63-71.

Moraczewska, A. (2008), Transformacja funkcji granic Polski, Wydawnictwo UMCS, Lublin.

Newman, D., A.Passi, (2001), Rethinking boundaries in political geography, in: Antonisch M., Kolossov V., Pagnini, M. P. (eds.), Europe between political geography and geopolitics, Societa Geografica Italiana, 1, Roma, 301-316.

Polski, J. (ed.) (1997), Strategia rozwoju Euroregionu Bug, Euroregion Bug, 16, Norbertinum, Lublin.

Ricq, C. (1995), Handbook on transfrontier co-operation for local and regional authorities in Europe, Council of Europe, Strasbourg.

Wspólna polsko-ukraińska strategia wspótpracy transgranicznej, Lubelskie, Podkarpackie, Wolyńskie, Lwowskie 2005-2015, (2005), Europejskie Centrum Integracji Współpracy Samorządowej „Dom Europy”, Lublin.

Żuchowski, W. (2005), Środowisko geograficzne, in: Kawałko B. and Miszczuk A. (eds.), Pogranicze polsko-ukraińskie. Środowisko. Spoleczeństwo. Gospodarka, WSZiA, Zamość, 29-49.

$<$ http://www.stat.gov.pl/cps/rde/xbcr/rzesz/ASSETS_badanie_obrotow_IIIkw_2009.pdf> 
http://rcin.org.pl 